\title{
Protecting the musicians and/or the record industry? On the history of 'neighbouring rights' and the role of Fascist Italy
}

\author{
Rasmus Fleischer* \\ Department of Economic History, Stockholm University
}

The early history of the so-called 'neighbouring rights', as part of the history of copyright, has so far been given very little attention by scholars. This article sheds light on a European contest over the rights in sound recordings during the 1930s, 1940s and 1950s. This forms an important part of the background to the Rome Convention of 1961. The article first looks separately at how musicians' unions and the record industry were raising different demands for protective legislation, motivated by the use of new electronic media. At the beginning, no one imagined that these protections would be bundled together as 'neighbouring rights'. While the International Labour Organization (ILO) put great efforts into creating a convention protecting only the performers, another actor turned out to be more influential in the long run, proposing a hierarchical bundling of rights in which only record companies were entitled to compensation for the use of recordings. This actor was the Fascist government of Italy. The article argues that there are some continuities from the legal philosophy of Italian Fascism to the system of 'neighbouring rights' established in the Rome Convention.

Keywords: music, technology, copyright, neighbouring rights, Rome Convention, International Labour Organization (ILO), International Federation of the Phonographic Industry (IFPI), Fascism

\section{INTRODUCTION}

In the history of music copyright, twentieth-century developments may be periodized in three phases, each one associated with a different treaty. ${ }^{1}$ First was the era of the author, with the interest of composers remaining as the given centre for all discussion, and the Berne Convention as the principal vehicle for international recognition. This was followed by the neighbouring rights era, lasting from the 1930s to the 1960s, and characterized by the arbitration between different interests. The neighbouring rights era reached its apex in 1961 with the signing of the Rome Convention, intended for 'the protection of performers, producers of phonograms and broadcasting organizations'. During the latter part of the twentieth century, a stronger emphasis was put on

* I would like to thank Matt Stahl (University of Western Ontario) for the brilliant response given to an earlier version of this paper, as well as the two anonymous reviewers. The preparation of this article has been made possible through a postdoctoral grant from the Jan Wallander and Tom Hedelius Foundation.

1. D Laing, 'Copyright, Politics and the International Music Industry', in S Frith and L Marshall (eds), Music and Copyright (Routledge 2004) 70-85. 
the commercial significance of the cultural industries and copyright was gradually becoming a matter of trade policy, as asserted by the TRIPS agreement.

This article concerns the history of so-called neighbouring rights in Europe before the Rome Convention. Surprisingly enough, this is a far from well-charted territory in the existing literature. Historians concerned with music and copyright have tended to reserve their attention for the earlier (author-centred) and the later (trade-centred) developments of the twentieth century. A comprehensive history of the development of neighbouring rights is still waiting to be written. Meanwhile, the history behind the Rome Convention is usually presented in a cursory and overly simplified manner.

To name just one example, the widely used volume Music and Copyright from 2004 only assigns a few pages to the development of neighbouring rights. A tacit postulate of the narrative presented is that the three kinds of rights - musicians, record companies and broadcasting organizations - were always meant to be realized together, within one single convention. ${ }^{2}$ In other words, the bundled concept of neighbouring rights that was confirmed by the Rome Convention is projected backwards, making the history of these rights appear more straightforward than it actually was. The same kind of narrative is presented in the more recent book A Short History of Copyright. ${ }^{3}$

My intention with this article is to complicate that picture and to contribute to the deeper history of neighbouring rights. To this aim, I employ a large archival material from the Swedish copyright commission (Auktorrättskommittén) which was active in the period 1939-1956, ${ }^{4}$ but also the newspaper Musikern from the Swedish Musicians' Union, as well as some publications by legal scholars of Italy, published in the German journal Ufita. By combining these sources, I can demonstrate the disparity of the proposed models for regulating the 'secondary use' of musical recordings. Who would be entitled to what kinds of remuneration or control, and how to organize the collection of payments or the enforcement of rules? I will show that this was not simply a dispute between organized interests, but that it also became an ideological battleground in the highly polarized Europe of the 1930s.

As will be shown, the prevailing model for neighbouring rights was established in the 1930s, within a framework created by Italy's Fascist government. From 1933 onwards, this government distinguished itself internationally by its determined efforts to give the record industry stronger rights in recorded music. ${ }^{5}$

2. Laing (2004) (n 1) 76; cf. G Davies, 'The 50th Anniversary of the Rome Convention for the Protection of Performers, Producers of Phonograms and Broadcasting Organisations: Reflections on the Background and Importance of the Convention' (2012) 2(3) Queen Mary Journal of Intellectual Property 206-24.

3. B Atkinson and B Fitzgerald, A Short History of Copyright (Springer International Publishing, 2014) 85, 97-9.

4. The archives of Auktorrättskommittén are to be found, in two different but overlapping collections, at Swedish National Archives (Riksarkivet) in Stockholm. Source material found in these archives will be referenced using the reference code used by the National Archives, beginning with 'RA', followed by the number of the collection and then the number of the volume. Sources thus referenced are from the Swedish Copyright Commission, if no other author is specified.

5. I have previously presented these findings, within a broader and longer framework, in R Fleischer, Musikens politiska ekonomi: lagstiftningen, ljudmedierna och försvaret av den levande musiken, 1925-2000 (Ink bokförlag, 2012) 135-283. Parts of the same story have also been discussed in a recent work by the Swiss historian Monika Dommann, Autoren und Apparate: Die Geschichte des Copyrights im Medienwandel (Fischer, 2014) 170-87. 
This fact raises another question: Why was Fascist Italy, of all states, so interested in neighbouring rights in the 1930s?

Using the term 'fascist' here may seem provocative. I fully understand if some readers, at this point, suspect me of trying to smear the record industry, using a tactic of 'guilt by association'. Therefore, a clarification is in order: When I capitalize the term 'Fascist', this refers specifically to the movement, party and government led by Benito Mussolini in Italy. Many scholars consider Italian Fascism to have been a model for other national varieties of fascism, including German Nazism, and there is a lively debate about how to define the core of fascist ideology. ${ }^{6}$

However, my discussion on the role of Fascist Italy will not at all relate to the issue of 'generic fascism', but focus on the specific political conditions in Italy under Mussolini (1922-1943).

My investigation starts around 1930, which marks the outbreak of the Great Depression as well as the establishment of sound film in Europe. At that time, there did not exist any clear concept of neighbouring rights as a given bundle. The proposals for protecting musicians and record companies were raised and discussed separately. This fact will be reflected in the structure of my article.

First, I will discuss how European musicians' unions began to propose a protective legislation, concerned with rising unemployment as 'mechanical music' began to supplant 'live music'. In the following section, attention is shifted to the record industry that organized itself to demand a different kind of legal protection, motivated by the fear that radio broadcasting would cannibalize record sales.

From 1933 onwards, Italy's Fascist government acted as a pioneer by pushing for a new kind of legal protection for the record industry, and the article will discuss the possible reasons for these efforts, highlighting an important continuity from Fascist Italy to the Rome Convention. As a contrast, I then present the alternative model that was developed by the copyright commissions in the Nordic countries - a model which was far less generous to the record companies, but which was ultimately abandoned as the 'Italian' model gained momentum around 1950. My hope is that this contrast can illustrate the instability of intellectual property and the contingent moments of its history. With respect to the details of the history of copyright law under Fascism in Italy, however, there is much work yet to be done; I want to point out that original sources in the Italian language are lacking in the following investigation. My focus will rather be on comparison between conflicting proposals in the international arena in Europe.

\section{MUSICIANS' DEMANDS FOR RIGHTS IN THE 1930S}

Already in the late 1920s, musicians' unions in Europe had formulated loose proposals for a protective legislation, motivated by the fear that the broadcasting of music could harm the market for performing musicians. These proposals were sent to the International Labour Organization (ILO), which was a part of the League of Nations, headquartered in Geneva. In 1929 the ILO decided to take up the matter, and this marked the beginning of a long conflict between the ILO and the BIRPI (the predecessor of WIPO, which was responsible for administering the Berne Convention).

In 1931, a meeting was held between the ILO and the BIRPI organizations, together with Unesco (Paris) and Unidroit (Rome), resulting in an agreement that ILO would be

6. K Passmore, Fascism: A Very Short Introduction (Oxford University Press 2014) 10-32; R Paxton, 'The Five Stages of Fascism' (1998) 70(1) The Journal of Modern History 1-23. 
responsible for investigating the issue of performers' rights. The ILO's firm position was that a performer's right to secondary uses of musical recordings was not to be designed as an individual right, but as the solution to a collective problem for all professional musicians. According to them, the problem was one of 'technological unemployment'. When the ILO proposed the establishment of a performer's right, this was not conceived as much as an extension of the prevailing copyright system, but as an innovation in labour legislation.

This was very different from the kind of law that had been enacted by Germany in 1910 , which basically extended the author's right, meaning that an individual performer could claim copyright to a recording, as long as it could be argued that the interpretation constituted a unique adaptation of the musical work. In other words, that kind of right only benefitted soloists, while the majority of orchestra musicians still did not have any rights in their recordings. During the 1920s, similar laws were enacted by several other European countries, including Italy, which was hosting the 1928 congress for revision of the Berne Convention and proposed a similar clause to be included in the treaty. However, the majority of the congress maintained that exclusive rights should only be granted to authors, not to performers, and the proposal was rejected. ${ }^{7}$

When the ILO promoted performers' rights in the 1930s, this did not mean an individual right but a way to protect the profession as a whole. The basic argument for this protection had nothing to do with aesthetics. Rather, the ILO conceived this as a new kind of labour legislation, motivated by the economic problems caused by new media. This idea emerged gradually out of great confusion, where the very reproducibility of music had been the subject of a lively debate.

In the summer of 1929, European musicians' unions met at a conference in Brussels to discuss possible responses to the coming of sound film. They decided to pursue a dual strategy: on the one hand, unions would try propaganda, using cultural arguments against 'mechanization' to defend the use of 'live music' 8 in movie theatres. On the other hand, unions called for a taxation of 'mechanical music', with the specific aim of raising money that could guarantee the support of unemployed musicians and their families. That proposal was soon generalized to target not only movie theatres, but also restaurants, cafés and other places of commerce that now tended to replace orchestras with loudspeakers. ${ }^{9}$

7. G Lemon, 'Internationella Musiker Unions kongress i Paris Musikern 1927: 23; A Molin, 'PM med vissa uppgifter ang. behandlingen av frågan om utövande konstnärers rätt', 12 November 1936 (RA/320523/24); 'Promemoria angående grunderna för en reform av lagstiftningen om rätt till litterära och musikaliska verk', Swedish governmental investigation (SOU 1937: 18) 57-61; 'Auktorrättens "Droits voisins": materialsamling upprättad i Justitiedepartementet', unpublished collection of material from the Swedish Department of Justice (1953), kept by Sweden's Royal Library; I Löhr, Die Globalisierung geistiger Eigentumsrechte. Neue Strukturen internationaler Zusammenarbeit 1886-1952 (Vandenhoeck \& Ruprecht, 2010) 117-29, 219-20; Dommann (2014) (n 5) 172-82, 186.

8. It should be pointed out that 'live music' was a rather new concept, which did not exist before the late 1920s. Although sound recording technologies had been established for several decades, the idea of 'live music' (as opposed to 'canned' or 'mechanical' music) rather emerged in response to the use of electronic amplification.

9. P Deutscher, 'Tonfilm, grammofon och annan mekanisk musik Musikern 1929: 2; G Gille, 'Internationella Musikerunionen och tonfilmsfrågan Musikern 1929: 17; W Karlander, 'Internationella Musikerunionens förbundssammanträde dryftar tonfilmsspörsmålet' Musikern 1929: 18-19). 
On the other side of the ocean, the American Federation of Musicians (AFM) under the leadership of Joseph Weber was advocating the same kind of dual strategy. Their propaganda campaign involved advertisements in the press, warning against the dangers of 'mechanical music' and asking the public to join a 'Music Defense League'. ${ }^{10}$ Between mid-1929 and mid-1932, the Swedish Musicians' Union (SMU) was closely following the propaganda efforts of AFM, hoping that the public could still be convinced of the cultural superiority of live music. ${ }^{11}$

The Nordic Musicians' Union (NMU) was an umbrella organization for the musicians' unions in Denmark, Finland, Norway and Sweden. During the 1930s, the NMU held three congresses, each with the problems posed by 'mechanical music' as the main topic of discussion. At the 1931 congress in Stockholm, the NMU still followed their American colleagues, hoping that propaganda would suffice. ${ }^{12}$ However, in mid1932 worrying news arrived from America: the AFM reported these efforts were failing to influence the entertainment habits of the public.

The mechanization of music began to seem unstoppable. The board of the NMU decided on a change of strategy: rather than trying to halt mechanization, the role of musicians' unions would be to help support its victims. Thus the main demand was to introduce a special tax on 'mechanical music' in order to raise money for the support of unemployed musicians while they were looking for other jobs. This drastic revision of union strategy expressed a more pessimistic evaluation of the future of 'live music', but the issue wasn't yet settled.

At NMU's next congress in Oslo, 1934, the two previous strategies were combined into a new and innovative synthesis. The Nordic musicians' unions still demanded a special taxation of the public performance of recorded music - but this was no longer presented as just a matter of social security, but the beginning of a new kind of cultural policy. The money should be channelled into a special fund for supporting live music. This would not only create new employment for musicians, but also make possible the arrangement of concerts, open for the general public at no cost. The unions hoped that this would accomplish what earlier propaganda campaigns had failed to do: to make the younger generation appreciate the unique qualities of 'live music', limiting the demand for 'mechanical music'.

After the 1934 congress, this Nordic resolution was sent to musicians' unions worldwide and was met with a very positive response. After being signed by the AFM and by most European musicians' unions, the resolution was sent to the International Labour Organization (ILO) in Geneva. The unions hoped to enlist the ILO in the effort to install an international legislation for the protection of musicians, based on the principle of redistribution: taxation of 'mechanical music' for the financing of 'live music'. ${ }^{13}$

10. J Kraft, Stage to Studio: Musicians and the Sound Revolution, 1890-1950 (John Hopkins University Press 1996) 82-5; T Anderson, "Buried Under the Fecundity of his Own Creations": Reconsidering the Recording Bans of the American Federation of Musicians, 1942-1944 and 1948' (2004) 22(2) American Music 231.

11. J Weber, 'Den mekaniska musiken mot den mänskliga'Musikern 1929: 21; J Weber, 'Om en mekanisk man spelade harpa' Musikern 1930: 3; 'Världskrisen inom musikeryrket' Musikern 1930: 16; 'Amerika ett föregångsland även för musikerna' Musikern 1931: 10; J Weber, 'Vår kamp mot ljudfilmen' Musikern 1932: 14.

12. G Gille, 'Nordisk musikerunions kongress, 1931' Musikern 1931: 11.

13. Resolution from Nordic Musicians' Union from the congress in Oslo, May 1934 (Labour Movement Archives of Sweden, volume 2847/F/2/A/2); Declaration from the presidium of the Nordic Musicians' Union regarding the resolution from the congress in Oslo, December 1934 
In the 1940s, a similar kind of fund was actually realized in the US, after the notable 'recording bans' by the AFM, now under the more militant leadership of James Caesar Petrillo. This was not the result of legislation, but of labour action directed against the recording industry. The end result was the creation of the 'Music Performance Trust Fund', financing free concerts for the public through a small fee on every record sold. ${ }^{14}$ In a sense, this fund - which has survived to this day - is a limited realization of the idea proposed in the Nordic resolution of 1934. But the Nordic musicians' unions never targeted the record industry. They never saw a fundamental problem with mechanical reproduction of recorded music; instead they targeted the secondary use (or misuse) of recordings.

In the 1930s, the Nordic musicians' unions reasoned that gramophone records are produced for the use in private homes, while the work of musicians was to perform in public (although a minority also worked in recording studios). The use of records in public settings resulted in unemployment, impairing the conditions for musicians as a collective. The legislation proposed by unions was never presented as an individual right, but as a collective right for all professional musicians, motivated by the spectre of 'technological unemployment'. In other words this was seen as a matter of labour legislation to be promoted by the ILO. Yet, the unions hoped that the next planned congress of the Berne convention, to be held in Brussels in 1936, would present an opportunity to reach an international agreement on protecting the collective rights of musicians.

\section{THE RECORD INDUSTRY'S DEMANDS FOR RIGHTS IN THE 1930S}

During the depression of the early 1930s, record sales fell drastically. The record industry blamed radio and began to raise demands for new legislation that would allow them to control the broadcasting of recorded music. ${ }^{15}$

The world's first international congress for the record industry was held in Rome in November 1933, gathering industry leaders from Britain, France, Germany and Italy. The congress resulted in the founding of the IFPI (International Federation of the Phonographic Industry), but the initiative came from the association of Italian industry (Confindustria) and it was joined by high-ranking officials of Italy's Fascist government. While the IFPI's headquarters were situated in London, it maintained a close relationship with the Italian government throughout the 1930s. ${ }^{16}$

(Labour Movement Archives of Sweden, volume 2847/F/2/A/4); G Gille, 'Från unionskongressen i Oslo' Musikern 1934: 13; G Gille, 'Nordisk musikeraktion mot den mekaniska musiken' Musikern 1937: 14; CG Lemon and G Gille, 'Musikerorganisationernas kamp mot den mekaniska musiken' Musikern 1935: 11; G Gille, 'Musikeryrket och Nationernas Förbund' Musikern 1935: 19.

14. Anderson (2004) (n 10); Kraft (1996) (n 10) 137-61, 192.

15. S Frith, 'The Industrialization of Music', in A Bennet, B Shank and J Toynbee (eds), The Popular Music Studies Reader (Routledge, 2006).

16. R Thalheim, 'Der erste internationale Kongreß der phonographischen Industrie in Rom und die Gründung der internationalen Vereinigung der phonographischen Industrie' (1934) 7 Archiv für Urheber-, Film- und Theaterrecht (UFITA); R Thalheim, 'Der Schutz der Schallplatte nach der italienischen Verordnung vom 18. Februar 1937' (1938) 11 Archiv für Urheber-, Filmund Theaterrecht (UFITA); A Hemming-Sjöberg, "La Guerre des Disques". Grammofonskivan ur rättslig synpunkt' in Festskrift tillägnad Hans Excellens Riksmarskalken Juris Doktor Birger Ekeberg (Svensk juristtidning, Stockholm 1950). 
The chairman of the congress was the Italian lawyer Amadeo Giannini. Directly after the meeting, he published a programmatic article ${ }^{17}$ in which he described the paradoxical situation created by the proliferation of electronic media: gramophone recordings were now heard by more people than ever, while record sales were falling. According to the IFPI and its first lobbyist Giannini, this was absolutely unacceptable.

Two different kinds of legislation were technically conceivable, according to Giannini. The issue was really if the gramophone record was to be protected as an industrial product or as a work of art. According to the first alternative, the sound recording on a gramophone record could be protected as an industrial design under the Paris Convention for the Protection of Industrial Property. That would give the record company an exclusive right to allow the material reproduction of the record as an object. In other words, it would protect record companies against unfair competition from other record companies; however, it would not cover any secondary uses of the records, such as radio broadcasting.

In the interest of record companies, Giannini instead recommended a second alternative: to give the record company the status of an author, and protecting its rights under the Berne Convention. That would motivate an exclusive right covering not only the material reproduction of sound recordings, but also secondary use. According to Giannini, the record company actually fulfilled an artistic task in the series of decisions behind each recording: selecting the melodies to be recorded, selecting the musicians to enlist, selecting the room with the appropriate acoustic and the placement of microphones. At the same time, Giannini explicitly rejected the idea that musicians would contribute with something similarly artistic when they performed the music. Only producers, and not performers, were entitled to join the authors in the Berne Convention. ${ }^{18}$

Giannini's proposal was immediately countered by CISAC, the international organization of composers, who feared that the claims of the record industry would devalue their existing copyrights. This conflict was resolved by yet another Italian intervention: Confindustria invited IFPI and CISAC to a meeting held in Stresa in the summer of 1934. That meeting resulted in a joint declaration in favour of a new convention for the protection of record companies, but specified that this would be a new kind of sui generis right, not competing directly with the composers' copyright. Record companies were to enjoy an exclusive right to allow or forbid the mechanical reproduction of their material product. But as for the secondary uses of recorded music in radio, film and television', the companies would only be entitled to some level of economic compensation, not an exclusive right. It is striking that the Stresa declaration did not even mention the similar demands that had been raised by musicians' unions. It should also be noted that all participants in the meeting at Stresa seem to have come from Italy, Germany or Britain; some national sections of CISAC disagreed with the Stresa agreement, which they only learned about in retrospect. ${ }^{19}$

After the meetings in Rome (1933) and Stresa (1934), the Italian government found that the time was ripe for an international convention for the protection of the record

17. A Giannini, 'Rechtsprobleme der Schallplatte' (1934) 7 Archiv für Urheber-, Film- und Theaterrecht (UFITA).

18. Giannini (1934) (n 17); see also Thalheim (1934) (n 16); Thalheim (1938) (n 16).

19. Resolution from IFPI/CISAC-meeting in Stresa, July 1934, reproduced in a letter from a representative of the Swedish record industry to the Department of Justice, 27 July 1935 (RA/320523/26); SOU 1937: 18, p 64 (n 7); Hemming-Sjöberg (1950) (n 16) 249-50. 
industry. Invitations were sent out for a diplomatic conference to be held in Rome in December 1935, but the conference was cancelled as a result of Italy's military aggression against Ethiopia in October the same year, which severely damaged the diplomatic credibility of the Fascist regime; the League of Nations even decreed economic sanctions against Italy. ${ }^{20}$

The fall of 1935 must have been a great disappointment for the IFPI. But for Mussolini's government, the protection of the record industry's interests remained a priority matter. The government assigned the IFPI lobbyist Giannini to draft a new legislation, which came into effect in 1937. This gave Italian record companies a right to remuneration for secondary uses of their records, on the radio as well as in restaurants and other entertainment venues. The amount to be paid was to be decided by an arbitration panel overseen by the state - a construction in perfect accordance with the corporatist doctrines of the Fascist government. ${ }^{21}$ But this does not in itself answer the question why Fascist Italy appeared to be more interested than any other state in serving the interests of the international record industry during the 1930s. In fact, the Italian government kept up its efforts in this seemingly marginal area even during World War II.

\section{THE ROLE OF FASCIST ITALY}

After the Fascist seizure of power in 1922, Mussolini concentrated on consolidating his own regime and eliminating socialism in Italy. 'Fascism is not for export', he explained to foreign journalists. ${ }^{22}$ With the outbreak of the Great Depression, this changed. From 1930, the ideological current known as fascismo universale was officially embraced. Fascism was now presented as a 'third way', beyond liberal individualism and socialist collectivism that could be applied in every nation as a solution to the crisis. This kind of universalist fascism reached its zenith in the years $1933-1935 .^{23}$

In the early 1930s, Italy had tried to use the ILO as an arena for propagating Fascism as a model for a modern social policy. But the ILO insisted on the principle that workers as well as employers should be able to organize on their own, free from

20. SOU 1937: 18, p 65 (n 7); Thalheim (1938) (n 16); A Giannini, 'Der Schutz des Phonogramms' (1938) 11 Archiv für Urheber-, Film- und Theaterrecht (UFITA); Hemming-Sjöberg (1950) (n 16) 250; D Liebscher, Freude und Arbeit. Zur internationalen Freizeit- und Sozialpolitik des faschistischen Italien und des NS-Regimes (SH-Verlag, Köln 2009) 40-41; K Ferris, Everyday life in Fascist Venice, 1929-40 (Palgrave Macmillan, New York 2012) 125-8.

21. 'Italien: Bestimmungen über den Schutz der Erzeugnisse der phonographischen Industrie' (1937) 10 Archiv für Urheber-, Film- und Theaterrecht (UFITA); Thalheim (1938); Giannini (1938) (n 20).

22. M Berezin, 'The Organization of Political Ideology: Culture, State, and Theater in Fascist Italy' (1991) 56(5) American Sociological Review 639-51; L de Caprariis, "'Fascism for Export"? The Rise and Eclipse of the Fasci Italiani all'Estero' (2000) 35(2) Journal of Contemporary History 151-83.

23. M Ledeen, Universal Fascism: The Theory and Practice of the Fascist International, 1928-1936 (H. Fertig, New York 1972); J Whitman, 'Of Corporatism, Fascism, and the First New Deal' (1991) 39(4) The American Journal of Comparative Law 747-78; S Falasca-Zamponi, Fascist Spectacle: The Aesthetics of Power in Mussolini's Italy (University of California Press, 1997); M Berezin, Making the Fascist Self: The Political Culture of Inter-war Italy (Cornell University Press, 1997). 
government control. That principle was clearly not compatible with the Fascist form of governance. ${ }^{24}$

In September 1933, Nazi Germany and Fascist Italy joined forces to build a 'new international of labour' as an alternative to the ILO. The idea was presented at a mass meeting in Köln, featuring Robert Ley (leader of Kraft durch Freude) and Giuseppe Bottai (Italy's minister of corporations). ${ }^{25}$

In early 1939, the ILO decided that the time was ripe for an international convention on performers' rights. A report was sent out to all member states in February, but before the comments had been collected and analysed, the outbreak of World War II would effectively freeze the process for ten years. Very soon after the ILO took that initiative, in April 1939 a new committee was assigned in Italy to prepare an international convention on the rights of musical performers and producers. This assignment was clearly an act of opposition towards the ILO. The initiative came from the eminent lawyer Eduardo Piola-Caselli (whose ideas will be analysed below), working together with the Rome-based International Institute for the Unification of Private Law (later known as Unidroit) which had been founded by Mussolini's government in 1926.

The committee also recruited legal experts from the USA and Germany, most importantly Fritz Ostertag who had just retired from his position as director of the BIRPI. This appointment indicates that the Italians knew how to exploit the tenyear-old conflict between Berne and Geneva.

The work of the committee progressed with remarkable speed. After only three months, they met in Samaden (Switzerland) ${ }^{26}$ and agreed on a proposal for an international convention. Just before the outbreak of World War II, the Samaden proposal was sent to the Belgian government, which was responsible for the next conference for the revision of the Berne convention.

According to the so-called Samaden proposal, musical performers would be entitled to remuneration when their recordings were broadcast on the radio, but not for other kinds of secondary use (ie loudspeakers). But the record companies would get money for all kinds of secondary use. Thus, the committee proposed a hierarchical system of unequal rights, favouring producers over performers. But the main innovation of the Samaden proposal was in the very ambition to merge the rights of performers and producers into one single convention. This was an approach in clear contrast to the convention proposed by the ILO, which would only protect the rights of performers, while the possible protection of record companies was regarded as a different matter. ${ }^{27}$

The German journal Ufita published a number of articles by eminent lawyers from Italy, discussing how new rights for musical performers and producers could be integrated with the existing copyright system. The three most prominent names in this

24. G Rodgers, E Lee, L Swepston and J Van Daele, The International Labour Organization and the Quest for Social Justice, 1919-2009 (International Labour Office, Geneva 2009) 28.

25. Liebscher (2009) (n 20) 13-14.

26. At this time the official name of this village was still the German 'Samaden', but a few years later it was changed to 'Samedan' in the Romansh language.

27. A du Pasquirer, 'Der Samadener Konventions-Entwurf und der Schallplattenhersteller' (1941) 14 Archiv für Urheber-, Film- und Theaterrecht (UFITA); Le Droit d'Auteur, October 1940, pp 109-11; Le Droit d'Auteur, November 1940, pp 121-5; Le Droit d'Auteur, December 1940, pp 133-8; E Hedfeldt, 'Om lekares rätt', in Festskrift tillägnad professor emeritus, juris doktor Gösta Eberstein (Norstedts, Stockholm 1950); see also Dommann (2014) (n 5) 175-82. The importance of the Samaden Draft is also acknowledged by Gillian Davies (2012) (n 2), although she does not consider the political background, ie the conflict between the Italian government and the ILO. 
context were Amadeo Giannini, Valerio de Sanctis and Eduardo Piola-Caselli. While Giannini here appears as a mere lobbyist for the record industry, the latter two stand out for their sophisticated attempts to ground their arguments in a Fascist legal philosophy.

Valerio de Sanctis would play an important role in the establishment of neighbouring rights, being one of the international experts who prepared the text of the Rome Convention in the 1950s. In the 1930s he was the lawyer of the SIAE, Italy's collecting society for composers and publishers of music, and an apparently ardent Fascist. In an article written in 1933 de Sanctis proclaimed 'the victory of the fascist idea in the world', ${ }^{28}$ referring to this idea as a 'German-Italian' synthesis in which the state is redefined so as to overcome liberal individualism as well as socialist collectivism. Here he presented the collective management of copyright as a prototype for the fascist organization of all industries. While private property should be protected, the participants in the market should not be able to exercise their rights individually, but only through specific organizations with mandates limited by the state. ${ }^{29}$

Eduardo Piola-Caselli expressed a similar kind of Fascist enthusiasm over Italy's new copyright legislation, enacted in 1941. He described this as nothing less than a revolution, which would eliminate 'the traditional individualist and liberal foundations of all civil law', replacing these with a new foundation derived from the Fascist Labour Charter from 1927. ${ }^{30}$ As an example of this formula, he mentioned the specific way of regulating the rights of performers, not as an exclusive right but as a right to compensation (droit pécuniare) in the context of a labour legislation, based on a corporatist vision of the organic unity of economy and state. ${ }^{31}$ In other words, de Sanctis and Piola-Caselli did not simply think that the use of recorded music should be regulated in a way that accorded with a general direction of the legal, political and economic system of Fascist Italy - they really seem to have believed that the music industry could become a kind of avant-garde for the Fascist reorganization of the economy.

Before 1941, only one country had legislation on special rights for musical performers and producers, namely Austria. Without going into the details of that law, it may be noted that it was enacted by the authoritarian regime under Kurt Schuschnigg, who was strongly influenced by Italian Fascism.

Italy's new copyright law, enacted in 1941, did indeed contain innovations. One major innovation in Italy's new copyright law was that it tried to merge the rights of musical performers and producers into one singular system. The chapter on neighbouring rights expressed a clear hierarchy: producers at the top, broadcasters second, performers only third. It confirmed the principle of the Samaden proposal, that only the record companies, not the musicians, should be entitled to money when recorded

28. This formulation ('der Sieg der faschistischen Idee in der Welt') obviously not only referred to Italian Fascism, but to a generic concept of fascism. Therefore, I will not capitalize the term 'fascist' when reproducing the message of this particular article.

29. V de Sanctis, 'Urheberrecht und Interesse der Allgemeinheit' (1934) 7 Archiv für Urheber-, Film- und Theaterrecht (UFITA); see also V de Sanctis, 'Das Urheberrecht und die Grundsätze des korporativen Systems' (1938) 38 Gewerblicher Rechtsschutz und Urheberrecht. Auslands- und internationaler Teil.

30. E Piola-Caselli, 'Zur Rechtsgrundlage des Urheberrechts nach italienischer und deutscher Auffassung' (1942) 15 Archiv für Urheber-, Film- und Theaterrecht (UFITA).

31. E Piola-Caselli, 'Die Regelung der Konflikte zwischen dem Urheberrecht und manchen benachbarten oder ähnlichen Rechten' (1938) 11 Archiv für Urheber-, Film- und Theaterrecht (UFITA). 
music is performed over loudspeakers in restaurants. ${ }^{32}$ At the same time, the law confirmed that the Fascist government of Italy held a stronger interest in the politics of new media than most other governments in Europe. ${ }^{33}$

\section{ALL ROADS LEAD TO ROME}

In early 1939 a definitive break occurred between the two international projects aiming at establishing new rights in the use of recorded music. On the one hand, the ILO aimed at creating a convention for the protection of musical performers. On the other hand, the Italian government and Unidroit wanted to include several kinds of neighbouring rights in one single convention, granting some rights to the performers but the strongest rights to the record companies. While the first project was supported by musicians' unions, the latter was backed by the IFPI. I will henceforth name these respective projects 'the Geneva Project' and 'the Rome Project'.

As Europe moved towards a new war in 1939, the work of the ILO came to a standstill and the Geneva Project lost its momentum. To a certain degree, it was picked up by the Nordic countries, where government commissions between 1939 and 1949 made a significant effort to formulate their own model for protection of musical performers and producers. I will return to 'the Nordic Project' in the next section.

It would not be until 1948 that diplomatic negotiations on this matter were resumed on a European level. Before the Rome Convention was signed in 1961, the 1950s witnessed a series of disputes between Geneva and Berne, played out through a shifting pattern of conflicts and tactical alliances between the organizations for musicians, composers, broadcasters and record companies, as well as national governments and UN agencies. But this messy process was still following the general direction that had been pointed out in the Samaden Draft of 1939. What was started in Rome would also end in Rome.

In 1950, the secretary of the Swedish copyright commission noted that the most influential work on the neighbouring rights had been done within 'the Italian line of action', the beginning of which he dated to the establishment of the IFPI in 1933. 'Beneath the surface, one may glimpse a power game between economic and political interests, which are partly concealed in darkness', he wrote. ${ }^{34}$

The conference in Brussels for the revision of the Berne Convention that was to be held in 1935 was postponed several times, and did not finally take place until 1948. Musicians' unions as well as record companies and broadcasters were hoping for the congress to affirm the need to give them specific rights. But there was a strong resistance, especially from France, against the inclusion of neighbouring rights in the Berne Convention. The delegates only agreed on some general formulations about the need for member states to once again consider the protection of producers, broadcasters and performers (mentioned in this very order, corresponding to the hierarchy of rights in the Samaden proposal of 1939). The congress in Brussels also

32. Piola-Caselli (1942) (n 30); L di Franco, 'Urheberrecht und Arbeitsrecht in der neuen italienischen Gesetzgebung' (1944) 16 Archiv für Urheber-, Film- und Theaterrecht (UFITA); D Saunders, 'Italian Fascism, Legality and Author's Right', in J Milfull (ed), The Attractions of Fascism: Social Psychology and Aesthetics of the 'Triumph of the Right' (Berg, New York 1990) 215-37.

33. Dommann (2014) (n 5) 185.

34. Hedfeldt (1950) (n 27) 73. 
assigned a new organ of experts, the Permanent Committee of the Berne Union, and at its first meeting in September 1949 this committee decided to give new life to the tenyear-old Samaden Draft, which was now sent out for comments to all member states. ${ }^{35}$ From this point, the Rome Project can be named 'the Rome-Berne Project'.

At the very same time, the Geneva Project was resumed by the ILO; their efforts were still focused on an international convention that would protect the rights of musicians but not record companies. It is no surprise that the IFPI remained staunchly opposed to this project, nor that musicians' unions still supported it.

After World War II, the musicians' unions of Europe formed an International Federation of Musicians (FIM). From the very beginning, 'strategies against mechanization' was on the top of its agenda. The FIM decided to pursue a double strategy, just as in the early 1930s. In the short term, musicians demanded compensation for the use of recorded music - money that should benefit unemployed musicians, not reward individual musicians whose recordings had become hits. But in the longer term, the aim of the FIM was to limit the use of recorded music for public performance in order to create more employment through live music. The FIM hoped that the ILO would help them to achieve this latter aim. ${ }^{36}$

The ILO summoned a new committee to discuss the 'rights of performers in broadcasting, television and the mechanical reproduction of sounds', meeting for the first time in October 1949. As with all ILO committees, it had a 'tripartite' construction, with delegations representing labour unions, employers' associations and member states. In this case, the first side was made up of musicians' unions (the FIM and the AFM) who put forth the radical demand that musicians should be given an exclusive right over the secondary use of their recordings. The unions were already planning for such a right to be exercised by the unions in order to safeguard employment for live orchestras.

But the employers' side, led by the IFPI's chairman Brian Bramall, was strongly opposed to the very idea of a special convention for performers' rights, and could effectively apply the brakes on the whole project. The charter of the ILO defines it as an organization for consensus-building; it cannot proceed with a proposal without the agreement of a majority within all three parties: governments, workers, employers. The 1949 meeting decided not to allow the ILO secretariat to take any further steps towards a convention, unless it was made in coordination with the organs of the Berne convention (the BIRPI and the Permanent Committee). And the latter organs insisted in keeping the Samaden Draft - once designed in open opposition to the ILO - as the starting point for all discussion. In other words, the Rome-Berne Project prevailed because it was anchored in an institution with routines far more flexible than those of the ILO. While the IFPI could apply the brakes to the Geneva Project, the FIM

35. Hemming-Sjöberg (1950) (n 16); 'Handlingar ang konferensen i Bruxelles 1948' (RA/ 320523/12); Memorandum about the Rome Draft from the Swedish Copyright Committee, May 1953, stored in a collection of materials labelled "Auktorrättens "droits voisins" at the Swedish Royal Library; G Bodenhausen, 'Protection of "Neighboring Rights"' (1954) 19(2) Law and Contemporary Problems 156-71; T Hesser, 'PM ang. pågående arbeten att genomföra ett internationellt skydd för utövande konstnärer m.fl.', March 1956 (RA/322228/3); undated and untitled memorandum from the Swedish Copyright Committee, approx. 1956 (RA/ 320523/18).

36. S Wassmouth, 'På förbundskongress i York' Musikern 1947: 13; 'Internationella musikerfederationen startar sin verksamhet' Musikern 1949: 1; S Wassmouth, 'Internationella Musikerfederationens första styrelsesammanträde' Musikern 1949: 2; S Wassmouth, 'Internationella Musikerfederationens (FIM's) första ordinarie kongress' Musikern 1949: 11. 
could not do the same for the Rome-Berne Project, having merely the status of observers. ${ }^{37}$ In other words, the institutional set-up was tilted in favour of the record companies, giving these a veto that the labour unions did not have.

The Permanent Committee of the Berne Convention called two expert conferences for negotiating an international convention based on the Samaden Draft. The first meeting was held in Lisbon in 1950, the second in Rome in late 1951; the latter resulted in the so-called Rome Draft (not to be confused with the final Rome Convention). For most of the 1950s, all parties involved seem to have believed that the Rome Draft would become the basis of an actual convention. Although the balance of rights between performers, producers and broadcasters was still an issue, the larger dispute concerned how strong these neighbouring rights should be in relation to the rights of authors already guaranteed in the Berne Convention. ${ }^{38}$ However, the complex negotiations during the rest of the 1950s must fall outside the scope of this article.

\section{THE NORDIC PROPOSAL AND ITS ABANDONMENT}

The spring of 1939 saw a definite split between the Geneva Project and the RomeBerne Project, as mentioned before. At the same time, the governments of Denmark, Finland, Norway and Sweden formed expert committees on copyright, with the aim of creating a common Nordic copyright legislation, including also some protection of musicians and record companies. Obviously, the Nordic governments no longer believed that the political situation in Europe would allow the establishment of a new treaty any time soon. Instead, they launched what I will call the Nordic Project.

The Swedish Copyright Committee (Auktorrättskommittén) organized a hearing in May 1939, inviting the Swedish musicians' union, the Swedish section of IFPI and the Swedish composers' collecting society (STIM) to present their different demands. Immediately after that meeting, the committee drafted a future Nordic legislation on neighbouring rights. According to this draft, musical performers should be given some rights in relation to the secondary use of musical recordings, 'including radio broadcasting as well as loudspeakers'. For the record companies, this draft was less satisfying: they would only be granted a right in the material reproduction of records, based on the view of a sound recording as a kind of industrial design. Record companies would get no rights in relation to the secondary uses of recordings. ${ }^{39}$

For the Swedish copyright commission, the rights of authors (composers) had the highest priority, followed by the rights of performers (musicians), while the producers (record companies) were placed at the bottom of the hierarchy of rights. This was very different from the Samaden principles, which placed producers over performers.

37. International Labour Organization, conference minutes, 'Advisory committee on salaried employees and professional workers (Geneva, 24-29 October 1949)' (RA/322228/6); S Wassmouth, 'Nytt från Internationella Musikerfederationen (FIM)' Musikern 1949: 7; S Wassmouth, 'Internationella arbetsbyrån' Musikern 1949: 11; S Wassmouth, 'Utifrån: International Federation of Musicians (FIM)' Musikern 1950: 2; B Bramall, 'Utifrån: Utövande artisters rättigheter' Musikern 1950: 11; Handwritten notes from meeting with Sven Wassmoth, September 1950 (RA/322228/11).

38. '25 års internationella förhandlingar om "Droits voisins", undated memorandum, approx. 1953 (RA/322228/5); Bodenhausen (1954) (n 35).

39. Swedish Copyright Committee, session minutes, 3 May 1939 (RA/320523/1); Swedish Copyright Committee, conference minutes, 8-20 May 1939 (RA/320523/8). 
Between 1939 and 1949, the Swedish and Nordic copyright committee was putting a lot of efforts into writing clauses concerning the secondary uses of musical recordings. While many details were changing, the hierarchy of rights was preserved. In other words, the Nordic Project can be presented as a more union-friendly one, in contrast to the industry-friendly tendency of the Rome-Berne Project. ${ }^{40}$

After the war, the IFPI began to worry about the direction the Nordic Project was taking. ${ }^{41}$ In 1947, its director, Brian Bramall, travelled from London to Stockholm to talk directly with the Swedish Copyright Commission. He not only demanded a right to compensation from radio broadcasters, but an exclusive right to control over all secondary use of records. He argued that if record companies were given such a strong protection, this would also indirectly protect musicians, so that there would be no need to legislate about performers' rights. The British Embassy in Stockholm also wrote a letter to Sweden's Prime Minister Tage Erlander, stressing the importance of protecting the rights of record companies. ${ }^{42}$

The Nordic copyright commissions did not accede to the demands of the IFPI. At their two final conferences (Oslo 1948 and Copenhagen 1949), they confirmed the principle that musicians should have a right to compensation for the secondary use of recorded music, on the radio as well as through loudspeakers. The record companies were granted no such right, but only a protection against the material reproduction of their records. ${ }^{43}$

However, this proposed law was never enacted by the Nordic countries. The direction of the process was abruptly changed after the expert meeting in Rome in late 1951. The result of the meeting was the so-called Rome Draft, which was then sent out by the BIRPI to the signatories of the Berne Convention with a request for comments. The answer from the Swedish government was worded by the Swedish Copyright Committee and the conclusion was harsh: the allocation of rights in the Rome Draft was 'not reasonable'. According to Sweden it was not possible to justify a system in which record companies were given an economic compensation which the

40. Draft copyright law, confirmed at the conference of the Nordic Copyright Committee in Helsinki, 29 September 1942 (RA/322228/1); Draft copyright law, 3 July 1943 (RA/322228/ 1); H Zetterberg, 'PM ang. rättsskydd för utövande konstnärers prestationer', 10 July 1943 (RA/322228/11); H Zetterberg, 'PM angående frågan om rättsskydd för grammofonskivor i Sverige', 16 November 1943 (RA/322228/11); Draft copyright law, 28 December 1946 (RA/ 320523/10); Draft copyright law, 15 February 1947 (RA/320523/10); Letter from the Swedish Musicians' Union to the Swedish Copyright Committee, 3 February 1948 (RA/320523/6); Draft copyright law, confirmed at the conference of the Nordic Copyright Committee in Oslo, February 1948 (RA/320523/11); Memorandum from the Norwegian Copyright Committee about the draft copyright law, February 1948 (RA/320523/11); Memorandum from the Swedish Copyright Committee about the draft copyright law, September 1949 (RA/322228/3); Draft copyright law, confirmed at the conference of the Nordic Copyright Committee in Copenhagen, SeptemberOctober 1949 (RA/320523/13); Draft copyright law, March 1950 (RA/320523/13).

41. Letter from Harald Flodin (Swedish IFPI) to the Swedish Copyright Committee, 30 May 1947 (RA/320523/7).

42. The archives of the Swedish Copyright Committee contains a series of letters from Brian Bramall (IFPI) and from Harald Flodin (Swedish IFPI), sent between April and August 1947, as well as a letter from J Thyne Henderson to Tage Erlander, 7 June 1947. To one of his letters, Brian Bramall also attached a memorandum entitled 'The effect of record broadcasting on record sales' (RA/322228/11). See also the letter from eight Swedish record companies, addressed to the King of Sweden, 12 August 1948 (RA/320523/26).

43. See note 40 . 
musicians were denied. Thus, Sweden's answer to the BIRPI was that the balance of interests in the Rome Draft was completely wrong, and the same message was also sent by the governments of Finland, Norway and the Netherlands. ${ }^{44}$

But the critics did not feel that they were in a position to radically change the outcome. The Nordic copyright committees assumed that the Rome Draft was very soon to be the basis for an international convention on neighbouring rights, and they did not want to stand outside such a convention. Therefore, they reluctantly dismissed the law proposal they had been working on for ten years, replacing it with another one, designed to be consistent with the Rome Draft. ${ }^{45}$

However, the Nordic committees found a way to marginally improve the outcome for musicians. In early 1952 the ILO arranged a conference to discuss the Rome Draft, where a certain Mr Lenoble, delegate of the French government, proposed a compromise. While musicians would still not be given any legal right to negotiate over compensation for the broadcasting of musical recordings, they could be given the right for a certain share of the compensation given to record companies. Later in 1952 the IFPI and the UER (European Radio Union) agreed that the so-called 'Lenoble proposal' was acceptable. Musicians' unions were still not happy, but the Nordic copyright committees agreed in 1953 to follow this principle. ${ }^{46}$

When the BIRPI sent out the Rome Draft for comments in 1952, they refused to attach the conclusions reached at the ILO meeting. Instead they attached a special comment written by George HC Bodenhausen, in which the Italian law from 1941 was highlighted as a model for its protection of neighbouring rights. ${ }^{47}$

Nordic compliance with the Rome Draft amounted to a cancellation of the early plans for compensating musicians for the public performance of recorded music through loudspeakers. The section on neighbouring rights in Sweden's new copyright law, enacted in 1960, only concerned one kind of secondary use, namely broadcasting. ${ }^{48}$ With this law, Sweden could immediately ratify the Rome Convention of 1961 .

44. T Hesser, 'Promemoria angående utkast till internationell konvention om skydd för utövande konstnärer, tillverkare av fonogram samt radioföretag', 20 May 1953 (RA/322228/3); Nordic Copyright Committee, session minutes, Stockholm 1-4 July 1953 (RA/320523/14); Official statement by the Swedish government regarding the Rome Draft, 23 November 1953, republished in the final report of the Swedish Copyright Commission, 'Upphovsmannarätt till litterära och konstnärliga verk' (SOU 1956: 25) 613-18; W Peter, 'Länderkritik des Romentwurfs (1951) zu einem internationalen Leistungsschutzabkommen' (1954) 18 Archiv für Urheber-, Film- und Theaterrecht (UFITA).

45. Nordic Copyright Committee, session minutes, Stockholm 1-4 July 1953 (RA/320523/14); Swedish Copyright Committee, memorandum on changes in the draft Nordic copyright law, December 1943 (RA/322228/3).

46. Personal notes from the ILO conference in Geneva, February 1952 (RA/322228/6); International Labour Office, 'Report of the Subcommittee on the Rights of Performers in Broadcasting, Television and the Mechanical Reproduction of Sound', conference minutes, March 1952 (RA/322228/6); S Wassmouth, 'Kampen för musikers och andra uppträdande konstnärers rättsskydd' Musikern 1952: 4; International Labour Office, 'Proposed international convention concerning the protection of performers, manufacturers of phonographic records and broadcasting organisations' 1957 (RA/322228/6).

47. '25 års internationella förhandlingar om "Droits voisins", undated memorandum, approx. 1953 (RA/322228/5); Bodenhausen (1954) (n 35).

48. Not until 1986 would Sweden broaden the scope of neighbouring rights to also cover public performances. 


\section{CONCLUSION}

The story told in this article is not one about the successful realization of a given bundle of rights. It is not a story of progress but one of contingency and politics. In the end, it becomes a story about how the record industry (IFPI) won while the musicians (FIM) lost. At the outset, however, both these groups raised separate demands for an exclusive right that would enable them to limit the secondary use of recorded music. While musicians worried mostly over public performance of music through loudspeakers, the record industry saw radio broadcasting as cannibalizing record sales.

Musicians' unions won the support of the ILO during the 1930s and 1950s, but the World War suspended all efforts for a special convention on performers' rights. The 1940s was a time of political fragmentation, with models for neighbouring rights being developed separately in the Northern and Southern parts of Europe, with very different results. The model proposed by the Nordic countries gave priority to musicians over the record industry, but this proposal was ultimately abandoned. The Rome Draft (1951) followed the Samaden Draft (1939) in promising the record companies special rights to economic compensation, while similar rights were denied the musicians. That hierarchy of rights would prevail also in the Rome Convention (1961).

Why did the record industry win while musicians lost? Part of the explanation probably has to do with the difference in organizational strength. Record companies were few and (from 1933 onwards) well organized internationally. Therefore, they could convince governments of their ability to organize a new system for economic compensation, in which musicians would also be allowed a share (according to the so-called Lenoble compromise). On the other hand, musicians were a multifaceted group, including anonymous wage-labourers in orchestras as well as freelancing soloists, usually organized in different unions, not to mention all the unorganized amateurs and part-time jazz musicians.

'It would be interesting to ask, as an exercise in contrafactual history', Monika Dommann writes, 'how the development of copyright would have turned out if World War II had never happened'. ${ }^{49}$ The contingency of neighbouring rights becomes apparent in the developments in 1939 discussed above. In retrospect, it is clear that the Samaden Draft (1939) was a milestone on the long road towards the Rome Convention. This document was produced in direct opposition to the ILO, within a framework provided by the Fascist government of Italy. The initiative came from Eduardo Piola-Caselli who had already declared a spiritual war against the 'liberal foundations of all civil law'. It can be concluded that legal scholars adhering to Fascist ideology made important contributions to the emerging idea of neighbouring rights. In particular, the Fascist government was very eager to assist the newly founded IFPI in the international arena.

What motivated these efforts by Fascist Italy? There does not seem to be any explicit connection to any positive ideal about the role of music under Fascism. The Italian scholars discussed in this article all show a remarkable lack of interest in aesthetic issues when discussing the rights of musicians and record companies. But the motives also do not seem to be based in the Italian record industry's narrow interest in profitability.

My hypothesis is that the reason behind the Italian interventions was not primarily cultural or economic, but political. From 1933 onwards, Mussolini's government

49. Dommann (2014) (n 5) 180, my translation. 
wanted to present Fascism as a global model for crisis management, superior to socialism and liberalism. The issue of neighbouring rights became an arena for public diplomacy. Technological change had led to a complex situation, with not only one but several interest groups affected by the secondary use of musical recordings. It is likely that this situation appeared as a perfect backdrop for demonstrating the Fascist model, aiming at the reconciliation of economic interests under the 'corporate state'. In this particular case, the Fascist solution was to reject the concept of exclusive or individual rights of musical performers, introducing instead a statutory licence while also maintaining a strict hierarchy in which the incomes of musicians were made dependent on the incomes of record companies.

I think the intersection of law, technology and crisis contains the key to understanding why Italy's Fascist government invested so much prestige in the issue of music, particularly in the regulation of the secondary use of musical recordings. This does not mean that the resulting model was inherently 'fascist'. It is indeed possible to imagine the same outcome even without the active participation of a fascist regime. But there is a vast political difference between the balance of rights that was proposed by the Nordic countries in the 1940s, and the model that was realized first by the Fascist government of Italy and later in the Rome Convention. Perhaps it is now time to unbundle the neighbouring rights and to once again question the prevailing balance of rights between musicians and record companies. 